2013

\title{
Assessment of Carbon Storage and Biomass on Minelands Reclaimed to Grassland Environments Using Landsat Spectral Indices
}

Tim Warner

West Virginia University, tim.warner@mail.wvu.edu

Follow this and additional works at: https://researchrepository.wvu.edu/faculty_publications

Part of the Geography Commons

\section{Digital Commons Citation}

Warner, Tim, "Assessment of Carbon Storage and Biomass on Minelands Reclaimed to Grassland Environments Using Landsat Spectral Indices" (2013). Faculty Scholarship. 1101.

https://researchrepository.wvu.edu/faculty_publications/1101 


\section{Applied Remote Sensing}

\section{Assessment of carbon storage and biomass on minelands reclaimed to grassland environments using Landsat spectral indices}

Sheila A. Kazar

Timothy A. Warner 


\title{
Assessment of carbon storage and biomass on minelands reclaimed to grassland environments using Landsat spectral indices
}

\author{
Sheila A. Kazar and Timothy A. Warner \\ West Virginia University, Department of Geology and Geography, 98 Beechurst Avenue, \\ 330 Brooks Hall, Morgantown, West Virginia 26506-6300 \\ sakazar@gmail.com
}

\begin{abstract}
This study investigated carbon (C) storage and biomass in grasslands of West Virginia reclaimed surface minesites. Mine-related disturbance and subsequent reclamation may be an important component of $\mathrm{C}$ cycling. Biomass and $\mathrm{C}$ storage generally increased for the first five years after reclamation, but then declined, suggesting a nonlinear pattern to vegetation recovery. Three 2007 Landsat 5 Thematic Mapper and Landsat 7 Enhanced Thematic Mapper Plus images were used to assess the potential to predict biomass from raw red and near infrared radiance, the tasseled cap transformation (TC), and four vegetation indices [normalized difference vegetation index, enhanced vegetation index (EVI), triangular vegetation index, and the soil adjusted vegetation index]. TC greenness and EVI were most strongly correlated with biomass and illustrate a modest potential for monitoring vegetation recovery in reclaimed minelands. Additionally, a number of regression models that included age since reclamation and spectral indices were statistically significant suggesting a temporal recovery pattern amongst minesites in this study. (c) 2013 Society of Photo-Optical Instrumentation Engineers (SPIE) [DOI: 10.1117/1.JRS.7.073583]
\end{abstract}

Keywords: carbon; surface mining; reclamation; tasseled cap; biomass.

Paper 11237 received Oct. 31, 2011; revised manuscript received Jan. 3, 2013; accepted for publication Feb. 12, 2013; published online Feb. 25, 2013.

\section{Introduction}

The U.S. Department of Interior's Office of Surface Mining (OSM) reports ${ }^{1}$ that in 2009, $1,802,316$ ha were permitted for surface coal mining or reclamation in the U.S., of which 200,846 ha are located in West Virginia. ${ }^{2}$ Since the passage of the Surface Mining Control and Reclamation Act (SMCRA) ${ }^{3}$ of 1977 (Public Law 95-87 Federal Register 3 August 1977, 445-532), regulations have required land transformed by surface mining to be reclaimed. For example, 7,030 ha in West Virginia were classified as newly re-vegetated under SMCRA regulations during the 2009 to 2010 evaluation period. ${ }^{2}$ The most common post-mining land use classification issued for reclamation permit on surface mined lands under SMCRA in West Virginia is hayland or pasture, although the natural vegetation of the region is mostly deciduous forest. ${ }^{4,5}$

Surface mine reclaimed grasslands tend to be relatively homogeneous in composition. Such grasslands are created to mitigate physical and aesthetic effects of mining at the lowest possible economic cost. ${ }^{6}$ SMCRA regulations require "a diverse and permanent vegetative cover capable of self-regeneration and plant succession and at least equal in extent of cover to the natural vegetation of the area" (Ref. 3). Initial seeding with concurrent nitrogen fertilization and subsequent fixation by plants aid in the speed of minesite recovery and thus bond release requirements. Grasses such as tall fescue, switch grass, and orchard grass, and herbaceous legumes are planted on reclaimed minesites to fix nitrogen levels in the soil, and control erosion. ${ }^{7}$ While this is an efficient method to regenerate vegetative cover, prevent erosion, and gain the release of the bond the mine company was required to post prior to mining, actual productivity of this "grassland environment" may be low because of poor soil conditions after reclamation is concluded. ${ }^{8,9}$

0091-3286/2013/\$25.00 () 2013 SPIE 
Monitoring such grassland environments is important for understanding how disturbance due to mining is changing the natural environment at the regional scale, for example across an entire state such as West Virginia. Ecosystem service losses, particularly losses in carbon (C) sequestration and storage as a result of surface mining land use conversion, have raised concerns. ${ }^{10,11}$ Simmons et al. ${ }^{12}$ found that severe disturbance related to surface mining may result in long-term effects on ecosystem processes such as nutrient cycling, and that subsequent recovery to comparable ecosystems could take decades to centuries. Reclamation of minesoils, and the ecosystem of the general mined area, depends on vegetation for improving soil physical, chemical, and biological properties of the disturbed site. ${ }^{10,13}$ Thus, the assessment of temporal trends in aboveground biomass and $\mathrm{C}$ storage in reclaimed surface mine grasslands may potentially provide additional insight into aboveground recovery patterns and productivity in these environments.

\subsection{Remote Sensing Vegetation Indices}

Remote sensing offers the potential for monitoring mineland reclamation status and $\mathrm{C}$ stocks across large areas. A common remote sensing method for monitoring vegetation involves the use of linear data transformations. ${ }^{14-17}$ Transformations known as vegetation indices (VI) are defined as dimensionless, spectro-radiometric measures of vegetation, and have been used as indicators of the relative abundance, density, and vigor of green vegetation. ${ }^{18-20}$ The most typical wavelengths used in vegetation studies are the red and near-infrared bands, although other bands have also been used. ${ }^{20}$ The reason for focusing on red and near-infrared is that these two wavelength regions tend to have particularly strong associations with vegetation. Specifically, green biomass tends to be negatively correlated with red reflectance, and positively correlated with infrared reflectance. ${ }^{21}$

The normalized difference vegetation index (NDVI) is one of the most commonly used vegetation indices. ${ }^{22-25}$

NDVI is defined as

$$
\mathrm{NDVI}=\frac{\rho_{\text {nir }}-\rho_{\text {red }}}{\rho_{\text {nir }}+\rho_{\text {red }}},
$$

where $\rho$ is the reflectance (atmospheric corrected), $\rho_{\text {red }}$ is red reflectance (atmospheric corrected), and $\rho_{\text {nir }}$ is near-infrared reflectance (atmospheric corrected).

NDVI has been used extensively in studies monitoring vegetation biophysical characteristics such as leaf area index and biomass of agricultural crops, ${ }^{18,26}$ as well as of rangeland and grassland ecosystems. ${ }^{21,27-34}$

A more recently developed variant of NDVI is the enhanced vegetation index (EVI), developed by the Moderate Resolution Imaging Spectroradiometer (MODIS) Land Discipline Group. ${ }^{35-37}$

EVI is defined as:

$$
\mathrm{EVI}=G \frac{\left(\rho_{\text {nir }}-\rho_{\text {red }}\right)}{\rho_{\text {nir }}+C_{1} \rho_{\text {red }}-C_{2} \rho_{\text {blue }}+L},
$$

where $G$ is the gain factor, set to $2.5 ; \rho_{\text {blue }}$ is blue reflectance (atmospheric corrected), $L$ is soil adjustment factor, set to 1.0 , and $C_{1}, C_{1}$ is coefficients which describe the use of the blue band in correction of the red band for atmospheric aerosol scattering, empirically determined to be 6.0 and 7.5 , respectively.

The EVI utilizes a soil-adjustment factor coupled with two coefficients, which normalize for aerosol scattering as well as variations in the spectral properties of the ground cover below the vegetation. In general, compared to NDVI, EVI is considered to have improved sensitivity to high biomass regions and improved vegetation monitoring capability. ${ }^{35,37,38}$

The tasseled cap (TC) is an orthogonal transformation that generates four rotated dimensions in Landsat Multispectral Scanner (MSS) data: soil brightness, vegetation greenness, yellow stuff, and nonsuch. ${ }^{39}$ This index rotates the MSS data cloud so that the majority of the information is contained in the first two rotated features, which are interpreted to be related directly to physical scene characteristics, hence their names. ${ }^{39}$ In an extension of the TC to six-band Landsat 
Thematic Mapper (TM) data, Crist and Cicone ${ }^{40}$ identified three spectral dimensions that define the planes of brightness, greenness, and wetness, as well as three unnamed dimensions. Pixels from areas dominated by exposed soil were found primarily distributed in the plane of brightness, and pixels from areas of varying vegetation cover in the plane of greenness. The zone of wetness lies between the planes of soil and vegetation, and is related to canopy and soil moisture.

TC is defined as

$$
\begin{aligned}
\text { Brightness }= & 0.35612057 \mathrm{TM} 1+0.39722874 \mathrm{TM} 2+0.39040367 \mathrm{TM} 3 \\
& +0.69658643 \mathrm{TM} 4+0.22862755 \mathrm{TM} 5+0.15959082 \mathrm{TM} 7, \\
\text { Greenness }= & -0.33438846 \mathrm{TM} 1+-0.35444216 \mathrm{TM} 2+-0.45557981 \mathrm{TM} 3 \\
& +0.69660177 \mathrm{TM} 4+-0.02421353 \mathrm{TM} 5+-0.26298637 \mathrm{TM} 7, \\
\text { Wetness }= & 0.26261884 \mathrm{TM} 1+0.21406704 \mathrm{TM} 2+0.09260517 \mathrm{TM} 3 \\
& +0.06560172 \mathrm{TM} 4-0.76286850 \mathrm{TM} 5-0.53884970 \mathrm{TM} 7,
\end{aligned}
$$

where TM $n$ is the Landsat Thematic Mapper band and $n$ is band number.

Note that, unlike the indices such as NDVI, which are regarded as generic indices applicable to multiple sensors, the TC coefficients are specific to Landsat TM, and thus for Eqs. (3)-(5), specific Landsat bands are indicated as variables, rather than more generic wavelength regions. Originally developed for agricultural applications, the TC has been applied in forest, grassland, and rangeland research in the last two decades..$^{30,41-44}$

Hybrid indices can be considered as a mixture between the ratio and the orthogonal indices. ${ }^{20}$ The soil-adjusted vegetation index (SAVI) uses a soil-brightness dependent correction factor $(S)$ that compensates for the difference in soil background conditions. Huete ${ }^{45}$ recommends a value of 0.5 for $S$, based on empirical observations.

SAVI is defined as

$$
\mathrm{SAVI}=\frac{(1+S)\left(\rho_{\mathrm{nir}}-\rho_{\mathrm{red}}\right)}{\rho_{\mathrm{nir}}+\rho_{\mathrm{red}}+S}
$$

Broge and Leblanc ${ }^{46}$ developed the triangular vegetation index (TVI), which describes the radiative energy absorbed by the leaf pigments as a function of the relative difference between red and NIR reflectance in conjunction with the magnitude of green reflectance. The TVI is calculated as the area of a triangle in spectral space with apices defined by the green peak, the chlorophyll absorption minimum, and the NIR shoulder. ${ }^{46}$

TVI is defined as

$$
\mathrm{TVI}=0.5\left[120\left(\rho_{\text {nir }}-\rho_{\text {green }}\right)-200\left(\rho_{\text {red }}-\rho_{\text {green }}\right)\right],
$$

where $\rho_{\text {green }}=$ green reflectance.

The application of VI data to minesites may not be straightforward. Biophysical responses of vegetation in these sites are confounded by prior mining disturbance and reclamation activities. Also, mature grassland may have a major component of senesced, non photosynthetically active vegetation, which has spectral properties that differ from actively growing, green vegetation. ${ }^{47}$ Specifically, senesced vegetation has a higher reflectance in the visible wavelengths than green vegetation. Thus, phenology is likely to have an important role in determining the effectiveness of different spectral indices ${ }^{36}$ though no studies have looked at this question within the context of grassland productivity. An additional complication for applying VIs to monitoring reclaimed minesites is that variations in soil spectral properties associated with disturbance artifacts such as haul roads and barren areas within many reclaimed sites may complicate the relationship between biomass and the spectral indices, even for the indices that have a soil adjustment factor. ${ }^{45}$ Finally, it is important to note that in minelands reclaimed to grassland environments, much of the $\mathrm{C}$ accumulation is likely to be below ground, ${ }^{10,48-50}$ and that remote sensing in general can only be used to characterize aboveground biomass change. 


\subsection{Objectives}

The objectives of this study were: (1) to determine if surface minesites in Monongalia and Preston counties, West Virginia, released after phase II reclamation, exhibit a distinctive temporal pattern in biomass and $\mathrm{C}$ accumulation during the period following reclamation, and (2) to explore the potential relationship between spectral vegetation indices, aboveground biomass, and temporal window of growing season for image acquisition, in reclaimed surface mine reclamation sites in Monongalia and Preston counties, West Virginia. To our knowledge, there have been no studies that address the effect of surface mining and reclamation on biophysical characteristics of aboveground vegetation over time, and the potential for monitoring reclaimed minesites with spectral indices. However, Simmons et al. ${ }^{12}$ compared the hydrology and aboveground and belowground $\mathrm{C}$, nitrogen, and phosphorus in relatively undisturbed watersheds and nearby reclaimed minelands.

\section{Methods}

\subsection{Study Site}

Nine reclaimed coal surface minesites in north central West Virginia, including seven sites in Monongalia County and two sites in Preston County were chosen for this study (Fig. 1). The minesites in this study vary in age since reclamation and bond status, and were reclaimed under the SMCRA reclamation categories of forestland, hayland/pastureland, industrial commercial, or public service (Table 1). Sites were chosen based on the following criteria: (1) phase II or phase III bond release, (2) within the north-central West Virginia region, and (3) accessible for sampling. The minesites range from 355 to $582 \mathrm{~m}$ in elevation and had a slope of $<10$ percent on average. Six out of the nine sites had a southern aspect while the remaining three sites had a primarily northwest aspect. The mines all have a similar geological context. The seven sites in Monongalia County were mined from the Pittsburgh coal seam, and the two Preston County sites from the Upper Freeport seam. The Pittsburgh seam and the Upper Freeport seam both contain high levels of sulfur that can lead to acid mine drainage. $^{51}$

Relative vegetation conditions of minesites are indicated by phase II release dates corresponding to $60 \%$ vegetation cover description ${ }^{52}$ (Table 1). The Payne and Guston Run (Guston) minesites have had their bonds completely released. However, complete bond release does not necessarily represent re-vegetation success at the time of release. Release of a minesite from bond requires only that a $90 \%$ vegetation cover has been established ${ }^{52}$ (Table 2), and the condition of vegetation, density of herbaceous cover, and relative soil condition at the time of release are not known. Also, vegetation conditions within each minesite do vary (Fig. 2). Therefore, caution should be exercised in making simple interpretations of landcover from the permit stage.

Monongalia and Preston counties have a temperate continental climate characterized by seasonal fluctuations in temperature, with hot humid summers followed by relatively cold winters. ${ }^{4}$ Mean annual temperature is $10.9^{\circ} \mathrm{C}$ and total mean annual precipitation is $112 \mathrm{~cm}$, based on a time period of 50 years (1952 to 2002). ${ }^{53}$ These two counties are within the range of the central hardwood region. Forests of this region are predominantly deciduous angiosperms, ${ }^{4}$ and are classified as part of the mixed mesophytic forest within the Cumberland and Allegheny Plateaus. ${ }^{54}$ Common tree species found in this area include yellow-poplar (Liriodendron tulipifera), red maple (Acer rubrum), sugar maple (Acer saccharum), eastern hemlock (Tsuga canadensis), and American basswood (Tilia Americana).

Soils in this region generally have a silty and loamy texture, a udic moisture regime, and include ultisols, altisols, and inceptisols. ${ }^{55,56}$ However, mine soils are anthropogenic in origin and differ from their original state because the drainage and underlying geology has changed. During the reclamation process, soils that were previously stockpiled are redistributed throughout the site to attain premining topsoil depth. ${ }^{48}$ Additional overburden material and chemical amendments may be added in the attempt to limit the effect of toxic spoil materials and to return the land to suitable $\mathrm{pH}$ and plant nutrient status. ${ }^{48}$ 


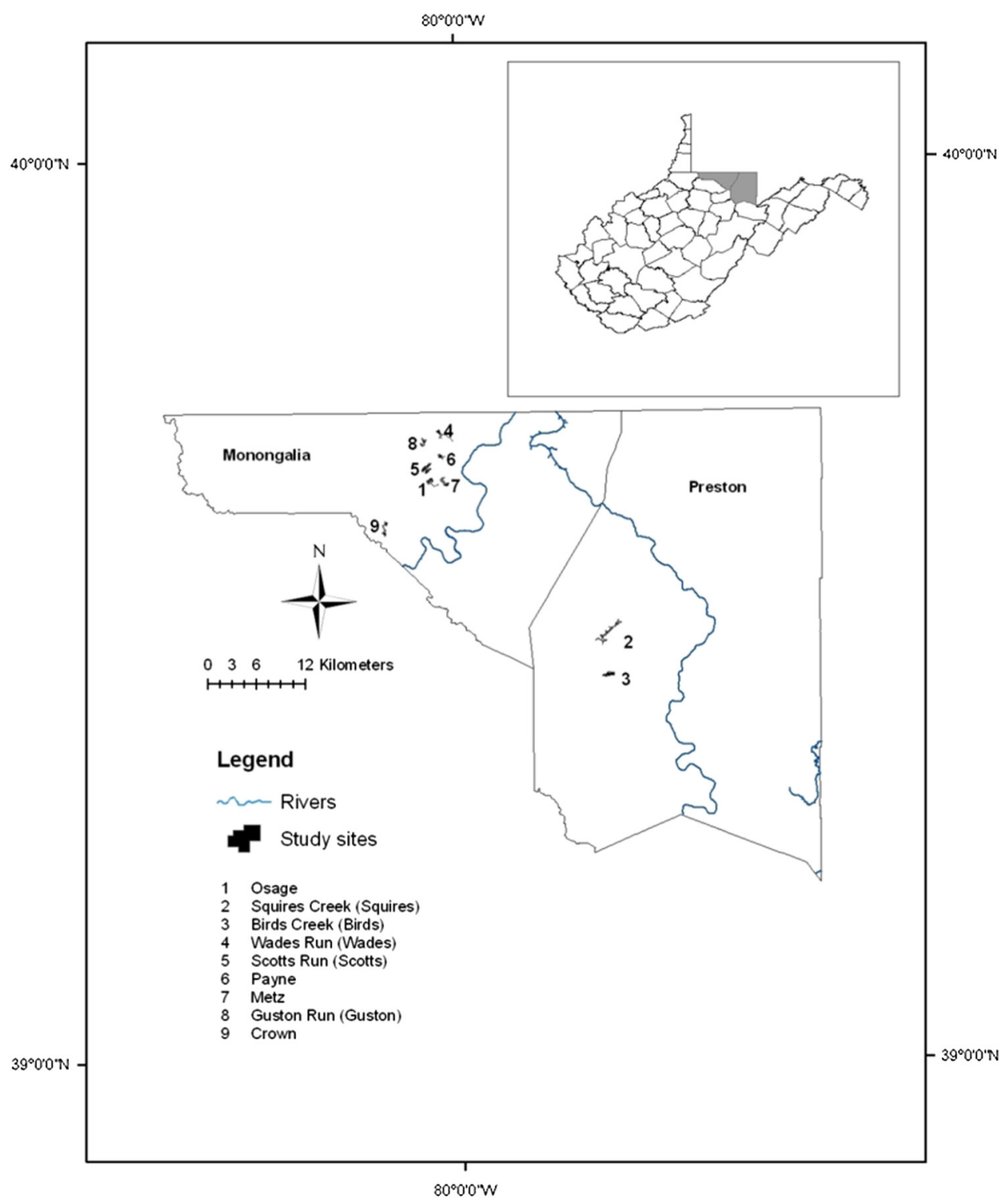

Fig. 1 Study sites within Monongalia and Preston counties, West Virginia. The locations of the nine reclaimed sites are shown.

\subsection{Chronosequence}

In this research, we use the concept of a chronosequence ${ }^{57-60}$ to investigate the pattern of $\mathrm{C}$ storage and vegetation recovery of minesites over an extended period of time, without having to study the same site for multiple decades. Our assumption is that, for the mines studied, time since reclamation is more important than any other variable, such as physiographic context and reclamation method, in determining the aboveground $\mathrm{C}$ grassland storage. This is a reasonable assumption because the other major variables that might influence $\mathrm{C}$ storage do not appear to vary notably amongst the minesites studied. As described in the previous section, the mine sites all have a similar physiographic context. In addition, reclamation activities are prescribed by SMCRA and implemented through state regulations, and this imposes a certain degree of uniformity in reclamation methods, even over the extended period of reclamation studied. Specifically, West Virginia's re-vegetation plan is governed by Title 38, which prescribes general procedures for all newly permitted mines regardless of post-mining land use. For example, the law specifies an established vegetation cover capable of stabilizing the soil from erosion, as well as the application of lime, fertilizer, and mulch according to individual site analysis ${ }^{61}$ However, it is important to acknowledge that chronosequence approach has its limitations, as it is 
Table 1 Location, area, age, bond-status, and post-mining land use of reclaimed surface minesites in study.

\begin{tabular}{|c|c|c|c|c|c|c|c|c|c|}
\hline $\begin{array}{l}\text { Site name } \\
\text { (\#) }\end{array}$ & Permit \# & $\begin{array}{l}\text { Latitude } \\
\qquad\left({ }^{\circ} \mathrm{N}\right)\end{array}$ & $\begin{array}{l}\text { Longitude } \\
\left({ }^{\circ} \mathrm{W}\right)\end{array}$ & $\begin{array}{l}\text { Area } \\
\text { (ha) }\end{array}$ & $\begin{array}{l}\text { Reclaimed } \\
\text { area (ha) }\end{array}$ & $\begin{array}{l}\text { Mining } \\
\text { permit } \\
\text { issue } \\
\text { date }\end{array}$ & $\begin{array}{l}\text { Phase II } \\
(60 \% \\
\text { veg) } \\
\text { release } \\
\text { date }\end{array}$ & $\begin{array}{l}\text { Postmining } \\
\text { land use }\end{array}$ & $\begin{array}{l}\text { Bond } \\
\text { status }\end{array}$ \\
\hline Osage (1) & S008080 & 39.38 & 80.22 & 31.16 & 23.67 & Aug-80 & Jan-01 & $\begin{array}{l}\text { Public } \\
\text { Service }\end{array}$ & Phase III \\
\hline $\begin{array}{l}\text { Squires Creek } \\
\text { (Squires) (2) }\end{array}$ & S011982 & 39.29 & 79.49 & 108.46 & 77.70 & Nov-82 & Dec-88 & $\begin{array}{l}\text { Hayland/ } \\
\text { pasture }\end{array}$ & Phase III \\
\hline $\begin{array}{l}\text { Birds Creek } \\
\text { (Birds) (3) }\end{array}$ & S102288 & 39.25 & 79.48 & 52.20 & 46.54 & Jul-89 & $1992^{a}$ & $\begin{array}{l}\text { Hayland/ } \\
\text { pasture }\end{array}$ & Phase III \\
\hline $\begin{array}{l}\text { Wades Run } \\
\text { (Wades) (4) }\end{array}$ & S103489 & 39.42 & 80.14 & 26.30 & 21.85 & $1985^{a}$ & Sep-99 & $\begin{array}{l}\text { Hayland/ } \\
\text { pasture }\end{array}$ & Phase III \\
\hline $\begin{array}{l}\text { Scotts Run } \\
\text { (Scotts) (5) }\end{array}$ & S100297 & 39.40 & 80.05 & 66.13 & 60.70 & Sep-97 & Jul-00 & $\begin{array}{l}\text { Industrial/ } \\
\text { Commercial }\end{array}$ & Phase III \\
\hline Payne (6) & $\mathrm{S} 103690$ & 39.40 & 80.23 & 28.94 & 28.94 & May-91 & Jun-02 & $\begin{array}{l}\text { Hayland/ } \\
\text { pasture }\end{array}$ & Released \\
\hline Metz (7) & $\mathrm{S} 100500$ & 39.38 & 80.12 & 37.23 & 36.02 & Sep-00 & Jul-03 & Forestland & Phase III \\
\hline $\begin{array}{l}\text { Guston Run } \\
\text { (Guston) (8) }\end{array}$ & S100200 & 39.41 & 80.35 & 27.19 & 21.57 & Jan-01 & Feb-03 & Forestland & Released \\
\hline Crown (9) & S200801 & 39.35 & 80.63 & 36.62 & 34.40 & Mar-03 & Jun-07 & $\begin{array}{l}\text { Hayland/ } \\
\text { pasture }\end{array}$ & Phase III \\
\hline
\end{tabular}

${ }^{a}$ Month not specified.

Table 2 Revegetation standards for phase III bond release in four minesite reclamation classes.

\begin{tabular}{lcc}
\hline \hline $\begin{array}{l}\text { Permitted post-mining } \\
\text { land use }\end{array}$ & $\begin{array}{c}\text { Ground cover } \\
(\%)\end{array}$ & $\begin{array}{c}\text { Tree canopy } \\
(\%)\end{array}$ \\
\hline Forestland & 90 & $25^{\mathrm{a}}$ \\
Hayland/pasture & 90 & 0 \\
Industrial/commercial & $\mathrm{b}$ & 0 \\
Public service & $\mathrm{b}$ & 0 \\
\hline \hline
\end{tabular}

Note: Source: WV Title 38C SR2

impossible to find completely identical sites for comparison, and this reduces the effectiveness of this approach. Minor differences between the sites are likely, for example in climate (especially due to the 227-m elevation gradient between the lowest and highest minesites in the study) and geology. In addition, reclamation practices may change over time or may vary between mining companies.

\subsection{Grassland Biomass and C Analysis}

Vegetation was sampled in nine minesites within the study area from mid-August through midSeptember of 2007. A 90-meter grid was placed over a map of the study area. From this gridded map, three $90-\mathrm{m} \times 90-\mathrm{m}$ plots were randomly selected within each minesite using a table of random numbers. Growing season biomass was measured by direct harvest, clipping five randomly placed, $0.25-\mathrm{m}^{2}$ circular quadrants within each plot. ${ }^{62}$ Each set of five samples was 


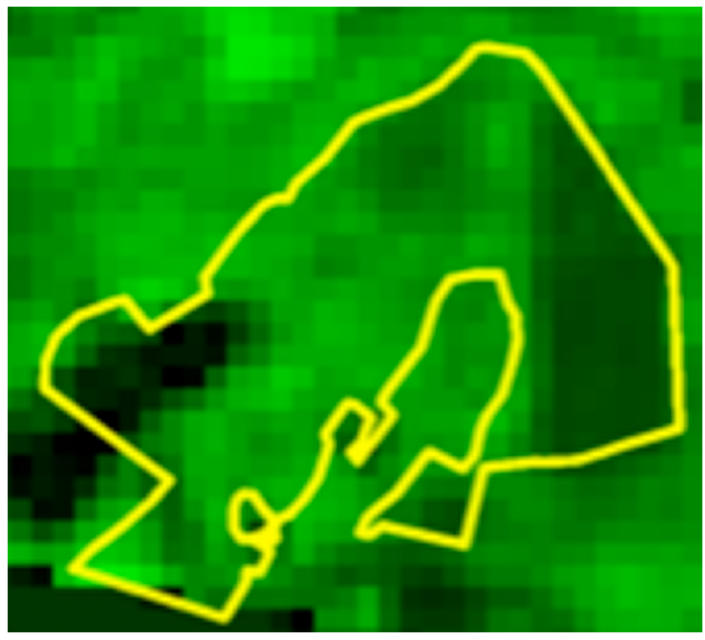

Fig. 2 Tasseled cap greenness image (2007) at Osage site, which was reclaimed in 2001.

averaged to provide a single plot value. Thus, there were initially 9 mines $\times 3$ plots per mine $=$ 27 samples. However, two plot values were eliminated because their locations were later found to coincide with the Landsat Enhanced Thematic Mapper Plus (ETM+) scan line corrector data gaps (see Sec. 2.4), and therefore the total sample size was reduced by 2 , resulting in $N=25$.

Vegetation was transported to the laboratory and dried for $24 \mathrm{~h}$ at $55^{\circ} \mathrm{C}$ in a Fisher Scientific Isotemp Oven, Model $630 \mathrm{G}$, and subsequently weighed. ${ }^{62} \mathrm{~A}$ small random portion of each dried grass sample was then ground in a Wiley mill and analyzed for carbon content using a NC 2500 Elemental Analyzer, ThermoQuest Italia. Acetanilide $\left(\mathrm{CH}_{3} \mathrm{CONHC}_{5} \mathrm{H}_{6}\right)$ was used to calibrate the analyzer.

\subsection{Spectral Indices}

A single 2007 Landsat 5 TM image (April 3) and two Landsat 7 ETM+ images from the same year (May 13 and September 18), path 17 row 33, were used in this study ${ }^{63}$ (Table 3). Three image dates were selected in an attempt to determine the time of year that most accurately depicts late-season biomass production. Ideally, additional images would have been acquired throughout the growing season, but all other dates during the growing season were cloud-covered. Cloudcover is a common problem in humid regions. The images were obtained from the USGS as orthorectified, terrain-corrected georeferenced products.

All image analysis was carried out using ERDAS Imagine 9.3 (Erdas, Atlanta, Georgia). The images were subsetted, and then radiometrically corrected using the CosT model. ${ }^{64}$ The CosT model corrects atmospheric scattering and absorption using a process in which raw pixel DN values are converted to apparent radiance and then reflectance. The atmospheric correction occurs in the last step of the model, where a multiplicative correction, expressed by the cosine of the solar zenith angle, is used as an approximation of atmospheric transmittance. ${ }^{64}$ Lu et al. ${ }^{65}$ found that the CosT correction is an effective approximation of more complex radiation transfer model-based approaches. The TM image, which has slightly different radiometric properties

Table 3 Dates of Landsat TM and ETM+ images used in study [Landsat world reference system (WRS) path 17 row 33].

\begin{tabular}{lcc}
\hline \hline Image type & Date & Pixel size \\
\hline Landsat TM & April 3, 2007 & 30 meter \\
Landsat ETM+ & May 13, 2007 & 30 meter \\
Landsat ETM+ & September 18, 2007 & 30 meter \\
\hline \hline
\end{tabular}


compared to the ETM+ image, was converted to equivalent ETM+ values via an empirical conversion based on Vogelmann et al. ${ }^{66}$

Studies using Landsat-7 Enhanced Thematic Mapper Plus (ETM+) are complicated by the May 2003 failure of the scan line corrector (SLC). Although there are gaps in the SLC-off data coverage, the radiometric quality of the data is equivalent to prefailure data. ${ }^{67,68}$ Various methods have been developed to fill the SLC-off gaps including: 1. using archived data to fill the gap, 2. segmentation models that use coincident spectral data to fill the image gaps, and 3. geostatistical interpolation approaches. ${ }^{69,70}$ Such gap-filling methods introduce uncertainty in the data, and therefore, for this study, data gaps present in the ETM+ images were not filled. Instead, a gap mask was created by combining the areas for which data was not available from each band of both of the ETM+ images. The gap mask was then used to eliminate data in all the images thus ensuring that the area covered by each image was identical.

Two Landsat TM bands, TM3 (red, 630 to $690 \mathrm{~nm}$ ) and TM4 (near infrared, 760 to $900 \mathrm{~nm}$ ), were compared to the field data. Additionally, five spectral transformations were computed: NDVI TC brightness (TC1), greenness (TC2), and wetness (TC3), SAVI, and TVI.

\subsection{Statistical Analysis}

All statistical analyses were carried out using SPSS software (SPSS, Chicago, Illinois). A one-way analysis of variance (ANOVA) was calculated to evaluate differences in biomass among mine sites. The ANOVA revealed an overall significant difference between minesites, $F(8,15)=4.81, p=0.004$. Subsequent Tukey tests revealed that the Osage mine site $(M=642.60, \mathrm{SD}=77.50)$ significantly differed from Wades Run (Wades) $(M=363.88$, $\mathrm{SD}=42.88)$, Squires Creek (Squires) $(M=299.59, \mathrm{SD}=2.81)$, and Birds Creek (Birds) $(M=366.72, \mathrm{SD}=84.98)$ mine sites, $p<0.05$, where $M$ is the mean and SD is standard deviation. The separability of Osage approached significance for Metz $(M=385.68, \mathrm{SD}=$ 139.16) and Crown $(M=356.80, \mathrm{SD}=131.04)$ mine sites, $p=0.06$. In addition, the separability of the Squires mine site $(M=299.59, \mathrm{SD}=2.81)$ approached significance for the Payne mine site $(M=587.25, \mathrm{SD}=16.15), p=0.06$. The separability of no other combination of mine site biomass was statistically significant.

Pearson product-moment correlation coefficients were calculated to summarize the relationship between biomass and the remote sensing transformations TM3, TM4, brightness, greenness and wetness, NDVI, EVI, SAVI, and TVI. Ordinary least squares regression models of standing crop and remotely-sensed variables were calculated. Because the linear relationship between minesite biomass and spectral indices may differ with age of the minesite, dummy variables were introduced into the regression model to assess the importance of age. The date of reclamation is available through the West Virginia Department of Environmental Protection public records, and therefore it would be feasible to add this information to a regional, remote sensingbased monitoring of reclaimed mine sites. Field estimates of biomass were treated as the dependent variable, and independent variables tested were: a dummy variable $(0=$ young, less than six years, $1=$ old, 6 years or more) and TM3, TM4, NDVI, TC brightness, greenness and wetness, EVI, SAVI, and TVI.

\section{Results}

\subsection{Biomass and C Content}

A comparison of 2007 in situ biomass to age of minesite relative to reclamation release suggests an initial period of generally increasing biomass for about six to seven years, after which values tend to decrease (Fig. 3, Table 4). Metz, reclaimed in 2003, and with the comparatively low biomass of $3857 \mathrm{~kg} \mathrm{ha}^{-1}$, is an exception to this overall trend. Squires, which was mined in 1982 and reclaimed in 1988, making it the oldest site, has the lowest biomass of the nine study sites at $3108 \mathrm{~kg} \mathrm{ha}^{-1}$ (Table 4). The second lowest biomass is found at Crown, which was reclaimed in 2007, and thus is the youngest site. Scotts Run (Scotts), Osage, and Payne, all reclaimed in the five to seven years prior to the field biomass collection, had relatively high 


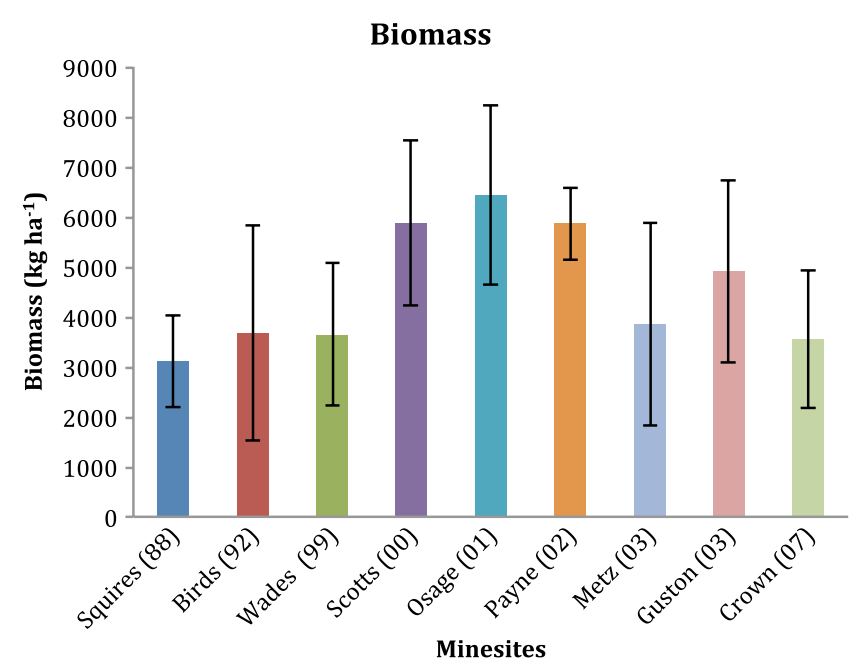

Fig. 3 In situ biomass measurements of samples acquired between mid-August and midSeptember 2007 for nine study sites. Phase II reclamation release date in parentheses. Error bars represent \pm 1 standard deviation.

Table 4 Summary statistics from field sampling in 2007 of the nine reclamation study sites. Years since phase II release refers to number of years between field sampling and phase II release.

\begin{tabular}{|c|c|c|c|c|c|c|}
\hline \multirow[b]{2}{*}{ Site } & \multirow[b]{2}{*}{$\begin{array}{l}\text { Phase II } \\
\text { release } \\
\text { date }\end{array}$} & \multirow[b]{2}{*}{$\begin{array}{l}\text { Years since } \\
\text { Phase II } \\
\text { release }\end{array}$} & \multicolumn{2}{|c|}{ Biomass } & \multicolumn{2}{|c|}{$\mathrm{C}$} \\
\hline & & & $\begin{array}{c}\text { Mean } \\
\left(\mathrm{kg} \mathrm{ha}^{-1}\right)\end{array}$ & $\begin{array}{l}\text { Std. } \\
\text { Dev. }\end{array}$ & $\begin{array}{c}\text { Mean } \\
\left(\mathrm{Mg} \mathrm{ha}^{-1}\right)\end{array}$ & $\begin{array}{l}\text { Std } \\
\text { Dev }\end{array}$ \\
\hline Crown & June 2007 & 1 & 3548 & 1386 & 1.51 & 0.57 \\
\hline Guston Run (Guston) & Feb 2003 & 4 & 4919 & 1831 & 2.28 & 0.82 \\
\hline Metz & July 2003 & 4 & 3857 & 2040 & 1.61 & 0.84 \\
\hline Payne & June 2002 & 5 & 5872 & 731 & 2.43 & 0.29 \\
\hline Osage & Jan 2001 & 6 & 6426 & 1782 & 2.75 & 0.70 \\
\hline Scotts Run (Scotts) & July 2000 & 7 & 5862 & 1647 & 2.63 & 0.92 \\
\hline Wades Run (Wades) & Sept 1999 & 8 & 3639 & 1417 & 1.60 & 0.68 \\
\hline Birds Creek (Birds) & $1992^{\mathrm{a}}$ & 15 & 3667 & 2152 & 1.56 & 0.87 \\
\hline Squires Creek (Squires) & Dec 1988 & 19 & 3108 & 913 & 1.33 & 0.39 \\
\hline
\end{tabular}

${ }^{a}$ Month not specified.

biomass values compared to the younger, more recently reclaimed sites such as Metz, Guston, and Crown.

Mean $\mathrm{C}$ percentage of the biomass varied little within the nine minesites (Fig. 4). Scotts had the highest $\mathrm{C}$ content, $46 \%$, while Payne and Metz had the lowest, at $41 \%$. The mean $\mathrm{C}$ percentage was $43 \%$. There is not a clear pattern of $\mathrm{C}$ percentage changing with age, although the lowest values are found associated with sites four to six years old (Metz, Payne, and Osage). Wades, Scotts Run, and Guston Run are notable for the greater variability of $\mathrm{C}$ percentage, and slightly higher mean values.

Because $\mathrm{C}$ percentage varied very little, total $\mathrm{C}$ content $\left(\mathrm{kg} \mathrm{ha}^{-1}\right)$ per site generally follows the same relative pattern over time as biomass (Fig. 5). Older sites that were reclaimed the longest, such as Squires, Birds, and Wades, exhibited a lower C content per hectare compared to Scotts Run, Osage, and Payne, which were reclaimed within the last five to seven years. 


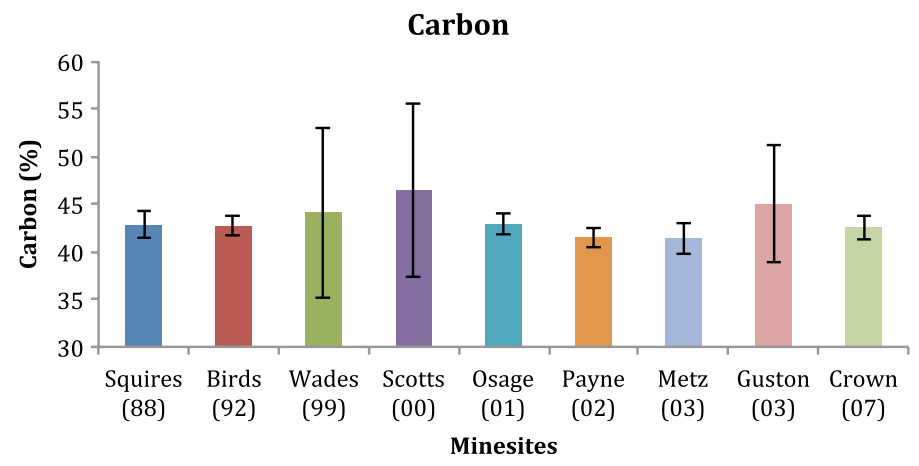

Fig. 4 Carbon percent for biomass samples acquired in mid-August through mid-September of 2007 in nine study sites. Phase II reclamation release date in parentheses. Error bars represent \pm 1 standard deviation.

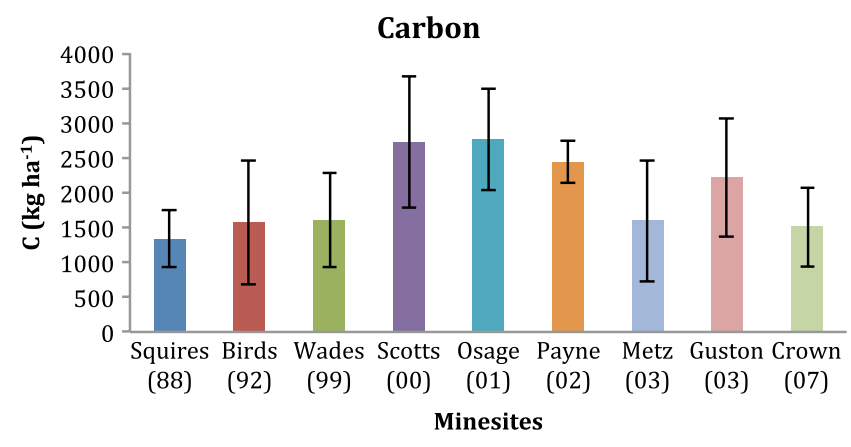

Fig. 5 Carbon content $\left(\mathrm{kg} \mathrm{ha}^{-1}\right)$ of biomass samples acquired in mid-August through midSeptember of 2007 in nine study sites. Phase II reclamation release date in parentheses. Error bars represent \pm 1 standard deviation.

However, Guston Run, reclaimed in 2003, has a relatively high C percent, C content, and biomass, compared to other recently reclaimed sites (Table 4, Figs. 3-5).

\subsection{Spectral-Biophysical Relationship}

\subsubsection{Correlations}

Pearson product-moment correlation coefficients $(r)$ were calculated for the variables of interest as a preliminary analysis to the multiple regression models, and are presented in Table 5. TM3 was found to be negatively associated with biomass for all three dates. TM3 is red radiance, and thus the greater the biomass, the more chlorophyll should absorb across this wavelength region, resulting in lower TM3 values. ${ }^{30}$ Therefore, this negative correlation was expected, although the association is not statistically significant at the 0.05 level. For all remaining spectral indices and for TM4, a positive association with biomass was found. It was somewhat surprising that brightness (TC1) was positively correlated with biomass for all three dates, since vegetation should have a lower albedo value than most soils. This positive correlation may suggest that the soil surface at these sites was spectrally unusual, with a low albedo, or that vegetation litter obscured the soil.

The correlations for the April 3 image were not statistically significant at the 0.05 level. This date in early April is the early growing season. Thus, it is perhaps not surprising that no statistical association was observed, although the trends are generally as expected.

Modest associations between some of the spectral indices and biomass were found for the May 13 and September 18 images. The strongest associations were observed for the May image, where greenness (TC2) and EVI were moderately correlated with biomass $(r=0.51, p<0.01)$. Only slightly lower correlations were observed for TVI and SAVI, with NDVI and wetness 
Table 5 Pearson product moment correlation coefficients $(r)$ for remote sensing indices for April 3, May 13, and September 18, 2007, satellite indices (including TM bands) and biomass $\left(\mathrm{g} \mathrm{m}^{-2}\right)$.

\begin{tabular}{llll}
\hline \hline & & Date & \\
\cline { 2 - 3 } Index & $4 / 3 / 2007$ & $5 / 13 / 2007$ & $9 / 18 / 2007$ \\
\hline TM3 & -0.04 & -0.04 & -0.04 \\
TM4 & 0.37 & 0.37 & $0.48^{\mathrm{a}}$ \\
TC1 & 0.24 & 0.35 & $0.48^{\mathrm{a}}$ \\
TC2 & 0.25 & $0.51^{\mathrm{b}}$ & 0.36 \\
TC3 & 0.03 & $0.43^{\mathrm{a}}$ & 0.02 \\
NDVI & 0.23 & $0.45^{\mathrm{a}}$ & 0.16 \\
EVI & 0.28 & $0.51^{\mathrm{b}}$ & 0.38 \\
TVI & 0.24 & $0.50^{\mathrm{a}}$ & $0.44^{\mathrm{a}}$ \\
SAVI & 0.28 & $0.50^{\mathrm{a}}$ & 0.35 \\
\hline \hline
\end{tabular}

Note: $N=25$

${ }^{\mathrm{a}} p<0.05$

${ }^{\mathrm{b}} p<0.01$

(TC3) having lower values, although all were significant at the 0.05 level. The TM4 correlation with biomass was not statistically significant.

For the September 18 image, a slightly different pattern emerges. No associations are significant at the 0.01 level. At the 0.05 significance level, the strongest associations are with TM4 and brightness (TC1) ( $r=0.48$ for both associations), and a slightly lower association is found for TVI $(r=0.44)$. No other vegetation index is statistically significant. This finding suggests that the spectral contrast between red and near-infrared, on which most spectral indices are developed, was not contributing to the spectral differentiation of vegetation, and this is further supported by the low correlation of NDVI and biomass $(r=0.16)$. However, to the extent that vegetation can be monitored spectrally, brightness (TC1) and near-infrared radiance (which

Table 6 Regression models of biomass by age of sites as predicted by the April 3, 2007, image: Brightness (TC1), Greenness (TC2), Wetness (TC3), normalized difference vegetation index (NDVI), enhanced vegetation index (EVI), triangular vegetation index (TVI), and soil-adjusted vegetation index $(\mathrm{SAVI})$. Old sites defined as reclaimed six years or more, younger sites as less than six years (dummy coded, $0=$ young, $1=$ old).

\begin{tabular}{ll}
\hline \hline Model & $R^{2}$ \\
\hline Biomass $=466.18-14.78(\mathrm{AGE})-18.54(\mathrm{TM} 3)$ & 0.00 \\
Biomass $=-60.51-14.75(\mathrm{AGE})+2093.81(\mathrm{TM} 4)$ & 0.14 \\
Biomass $=-272.88-71.99(\mathrm{AGE})+1992.20(\mathrm{TC} 1)$ & 0.11 \\
Biomass $=444.40-18.23(\mathrm{AGE})+1367.60(\mathrm{TC} 2)$ & 0.07 \\
Biomass $=461.50-15.81(\mathrm{AGE})-15.26(\mathrm{TC} 3)$ & 0.00 \\
Biomass $=272.77+17.35(\mathrm{AGE})+440.56(\mathrm{NDVI})$ & 0.06 \\
Biomass $=282.45+18.83(\mathrm{AGE})+243.15(\mathrm{EVI})$ & 0.08 \\
Biomass $=344.02+16.20(\mathrm{AGE})+12.31(\mathrm{TVI})$ & 0.06 \\
Biomass $=258.29+15.31(\mathrm{AGE})+765.73(\mathrm{SAVI})$ & 0.08 \\
\hline \hline
\end{tabular}

Note: $N=25,{ }^{\star} p<0.05$ 
is also heavily weighted in TC1), were important. Also notable is that the lowest association with biomass was observed for wetness $(r=0.02)$, suggesting that the biomass present had no spectrally discernible variation in moisture. All these observations are consistent with the suggestion that the grass had already started to senesce by the September image acquisition date.

\subsubsection{Regression models}

Having looked at the relationship between all variables, we now focus on the possibility of predicting biomass from the spectral indices using regression equations. The results of the

Table 7 Regression models of biomass by age of sites as predicted by the May 13, 2007, image: Brightness (TC1), Greenness (TC2), Wetness (TC3), normalized difference vegetation index (NDVI), enhanced vegetation index (EVI), triangular vegetation index (TVI), and soil-adjusted vegetation index (SAVI). Old sites defined as reclaimed six years or more, younger sites five years or less (dummy coded, $0=$ young, $1=$ old).

\begin{tabular}{ll}
\hline \hline Model & $R^{2}$ \\
\hline Biomass $=466.18-14.78(\mathrm{AGE})-18.54(\mathrm{TM} 3)$ & 0.00 \\
Biomass $=-60.51-14.75(\mathrm{AGE})+2093.81(\mathrm{TM} 4)$ & 0.14 \\
Biomass $=-802.29+1.19(\mathrm{AGE})+3392.09(\mathrm{TC} 1)$ & 0.12 \\
Biomass $=83.22+69.51(\mathrm{AGE})+2160.15(\mathrm{TC} 2)$ & $0.31^{\mathrm{a}}$ \\
Biomass $=855.90+48.41(\mathrm{AGE})+1883.90(\mathrm{TC} 3)$ & $0.21^{\mathrm{a}}$ \\
Biomass $=-272.55+61.04(\mathrm{AGE})+938.55(\mathrm{NDVI})$ & 0.24 \\
Biomass $=-117.29+80.11(\mathrm{AGE})+508.76(\mathrm{EVI})$ & $0.32^{\mathrm{a}}$ \\
Biomass $=42.89+79.37(\mathrm{AGE})+22.60(\mathrm{TVI})$ & $0.31^{\mathrm{a}}$ \\
Biomass $=-222.27+72.40(\mathrm{AGE})+1288.91(\mathrm{SAVI})$ & $0.30^{\mathrm{a}}$ \\
\hline \hline
\end{tabular}

Note: $N=25$

${ }^{\mathrm{a}} p<0.05$

Table 8 Regression models of biomass by age of sites as predicted by the Sept. 18, 2007, image: Brightness (TC1), Greenness (TC2), Wetness (TC3), normalized difference vegetation index (NDVI), enhanced vegetation index (EVI), triangular vegetation index (TVI), and soil-adjusted vegetation index (SAVI). Old sites defined as reclaimed six years or more, younger sites five years or less (dummy coded, $0=$ young, $1=$ old).

\begin{tabular}{lr}
\hline \hline Model & $R^{2}$ \\
\hline Biomass $=421.17-18.36(\mathrm{AGE})+767.87(\mathrm{TM} 3)$ & 0.01 \\
Biomass $=-391.72-6.48(\mathrm{AGE})+2092.97(\mathrm{TM} 4)$ & 0.23 \\
Biomass $=-653.56-20.01(\mathrm{AGE})+2599.79(\mathrm{TC} 1)$ & 0.24 \\
Biomass $=99.23-3.28(\mathrm{AGE})+1978.82(\mathrm{TC} 2)$ & 0.13 \\
Biomass $=470.65-14.85(\mathrm{AGE})+25.95(\mathrm{TC} 3)$ & 0.00 \\
Biomass $=89.80-5.06(\mathrm{AGE})+494.57(\mathrm{NDVI})$ & 0.02 \\
Biomass $=-113.84+9.14(\mathrm{AGE})+486.82(\mathrm{EVI})$ & 0.15 \\
Biomass $=-15.85+8.99(\mathrm{AGE})+22.66(\mathrm{TVI})$ & 0.19 \\
Biomass $=-202.63+1.15(\mathrm{AGE})+1220.21(\mathrm{SAVI})$ & 0.12 \\
\hline \hline
\end{tabular}

Note: $N=25, p<0.05$ 
regression models are shown in Tables 6, 7, and 8 for the April 3, May 13, and September 18, 2007, dates, respectively. The results for the April 3 (Table 6) and September 18 (Table 8) dates were not statistically significant at the 0.05 level, with values for the coefficient of determination $\left(R^{2}\right)$ that varied from 0.00 , to a maximum of 0.14 for TM4 in April, and 0.24 for TM4 in September.

For the May 13 data, statistically significant results (at $p<0.05$ ) were found for predicting biomass from AGE and greenness (TC2), wetness (TC3), EVI, TVI, or SAVI. The highest $R^{2}$ was found for EVI, with only marginally lower values for TVI and greenness (TC1).

\section{Discussion and Conclusions}

The pattern of increasing, then decreasing, biomass and $\mathrm{C}$ content in the nine minesites of the study following phase II reclamation release (Fig. 3) suggests a nonlinear recovery trajectory for the vegetation cover. In general, recently reclaimed sites such as Metz and Crown, reclaimed less than six years, exhibit a surge in vegetation growth after initial reseeding and nitrogen fertilization that is required by phase II release regulations. As soil develops and grass root systems deepen, the sites appear to become relatively more productive, leading to increased biomass. However, once the site has established a relatively permanent vegetation cover, biomass and C storage decline, possibly due to reduced intensity of management, drought or heat stress. Regardless of the reason for this pattern, the observed decline suggests that initial reclamation strategies do not result in sustained levels of production.

The fact that the correlation of the remotely sensed indices with biomass on the reclaimed mine sites was dependent on the time of year and the indices used (Table 5) confirmed expectations that phenology is important in monitoring grassland production. Previous studies have investigated grassland productivity using spectral indices, but usually for just a single date. $^{25,27,30}$

In early April, at the start of the growing season, the trends of the correlation of spectral indices and biomass are for the most part consistent with expectations, but were not statistically significant. Even with the inclusion of age since reclamation as a dummy variable, the regression model from spring was not statistically significant. In mid-September, at the end of the growing season, significant associations (at the 0.05 level) between the indices and biomass were found for just three variables, TM4, brightness (TC1), and TVI. The inclusion of brightness in this list, but not greenness (TC2), suggests that the biomass had senesced by this time. The September regression models, however, were not found to be statistically significant.

For the May 13 image, greenness (TC2), and EVI were statistically significant at the 0.01 level, and wetness (TC3), NDVI, and SAVI were significant at the 0.05 level. For the regression models, the combination of the dummy variable of AGE and indices of greenness (TC2), wetness (TC3), EVI, or SAVI were significant at the 0.05 level.

This study provides evidence that NDVI is not necessarily the variable that is most highly correlated with biomass, and reinforces the importance of identifying alternatives to this commonly used measure for vegetation monitoring, ${ }^{36}$ although some studies have found that NDVI does have broad application across many biomes. ${ }^{25}$ For the May data, NDVI the correlation with biomass was only the fifth strongest, and in September it was the second lowest. The NDVI regression model was not statistically significant. In contrast, $\mathrm{TVI}^{46}$ appears to be the most robust index, as it was the only index to have statistically significant correlation with biomass in both May and September, and also the regression model for estimating biomass was also statistically significant.

Considering the field work was carried out from Mid-August through mid-September, the finding that the indices generated from the May image resulted in the highest correlations with biomass prediction is notable in that it suggests that even a late spring acquisition can be used to generate relatively accurate predictions. In humid environments, the availability of satellite imagery tends to be constrained by cloud cover, and therefore being able to predict biomass over a wide range of dates during the growing season is potentially useful. In future work, it would be useful to identify more specifically the period of the growing season that spectral indices can be used reliably, for example whether similar or even more accurate predictions are 
found in June and July. Such a study should probably be based on field spectrometer measurements, to overcome the limitations in available satellite data.

In summary, remote sensing of biomass on minelands reclaimed to grassland, using moderate resolution satellite such as Landsat, appears to be feasible, at least if imagery can be obtained during the growing season, while the vegetation is still green. The spectral index used, however, should be chosen with care, because different indices appear to be most appropriate for monitoring biomass at different times of the year. NDVI is not the most reliable index for predicting biomass, but instead TC greenness or EVI should be used, or possibly TVI, which appears to be a relatively robust measure.

\section{Acknowledgments}

We would like to thank the NASA West Virginia Space Grant Consortium Graduate Research Fellowship Program and West Virginia View for the opportunity to conduct our research in West Virginia. The funding has allowed us to concentrate on laboratory work, statistical analyses, fieldwork, and establishing relationships with many people and agencies in the mining community.

\section{References}

1. Office of Surface Mining (OSM), http://www.osmre.gov (June 2010).

2. West Virginia Department of Environmental Protection (WVDEP), http://www.wvdep.org/ (June 2010).

3. Surface Mining Control and Reclamation Act (SMCRA) of 1977, Public Law 95-87.

4. R. R. Hicks Jr., Ecology and Management of Central Hardwood Forests, John Wiley and Sons, New York (1998).

5. K. D. Holl, "Long-term vegetation recovery on reclaimed coal surface mines in the eastern USA,” J. App. Ecol. 39(6), 960-970 (2002), http://dx.doi.org/10.1046/j.1365-2664.2002 .00767.x.

6. T. S. Brothers, "Surface-mine grasslands," Geogr. Rev. 80(3), 209-225 (1990), http://dx.doi .org/10.2307/215300.

7. D. C. Ditsch and M. Collins, "Reclamation considerations for pasture and hay lands receiving sixty-six centimeters or more precipitation annually," Chapter 13 in Reclamation of Drastically Disturbed Lands, R. I. Barnhisel, R. G. Darmody, and W. L. Daniels, Eds., pp. 595-613, ASA, CSSA, and SSSA, Madison, Wisconsin (2000).

8. J. A. Roberts et al., "Tall fescue production and nutrient status on southwest Virginia minesoils," J. Environ. Qual. 17(1), 55-62 (1988), http://dx.doi.org/10.2134/jeq1988 $.00472425001700010008 x$.

9. G. K. Evanylo et al., "Herbaceous vegetation productivity, persistence amid metals uptake on a biosolids-amended mine soil," J. Environ. Qual. 34(5), 1811-1819 (2005), http://dx .doi.org/10.2134/jeq2004.0329.

10. D. S. N. Ussiri and R. Lal, "Carbon sequestration in reclaimed minesoils," Crit. Rev. Plant Sci. 24(3), 151-165 (2005), http://dx.doi.org/10.1080/07352680591002147.

11. M. Sperow, "Carbon sequestration in reclaimed mine sites in seven east-central states," J. Environ. Qual. 35(4), 1428-1438 (2006), http://dx.doi.org/10.2134/jeq2005.0158.

12. J. A. Simmons et al., "Forest to reclaimed mine land use change leads to altered ecosystem structure and function," Ecol. App. 18(1), 104-118 (2008), http://dx.doi.org/10.1890/07 -1117.1 .

13. A. Bradshaw, "The use of natural processes in reclamation-advantages and difficulties," Landscape Urban Plann. 51(2), 89-100 (2000), http://dx.doi.org/10.1016/S0169-2046(00) 00099-2.

14. R. D. Jackson and A. R. Huete, "Interpreting vegetation indices," Prevent. Vet. Med. 11(3), 185-200 (1991), http://dx.doi.org/10.1016/S0167-5877(05)80004-2.

15. S. W. Todd, R. M. Hoffer, and D.G. Milchunas, "Comparison of four vegetation indices for estimating aboveground biomass on grazed and ungrazed rangeland," Chapter 5 in Looking 
to the Future with an Eye on the Past, A. J. Lewis, Ed., pp. 383-392, Elsevier, Amsterdam (1993).

16. T. M. Lillesand, R. W. Kiefer, and J. W. Chipman, Remote Sensing and Image Interpretation, John Wiley and Sons Inc., New York (2004).

17. D. A. Simms et al., "On the use of MODIS EVI to assess gross primary production of North American ecosystems," J. Geophys. Res. 111(G4), G04015 (2006), http://dx.doi.org/10 $.1029 / 2006 J G 000162$.

18. M. A. Gilabert, S. Gandia, and J. Melia, "Analysis of spectral-biophysical relationships for a corn canopy," Rem. Sens. Environ. 55(1), 11-20 (1996), http://dx.doi.org/10.1016/0034 $-4257(95) 00187-5$.

19. X. Zhang et al., "Monitoring vegetation phenology using MODIS," Rem. Sens. Environ. 84(3), 471-475 (2003), http://dx.doi.org/10.1016/S0034-4257(02)00135-9.

20. J. R. Jensen, Introductory Digital Image Processing: A Remote Sensing Perspective, Prentice Hall, New Jersey (2007).

21. H. D. Williamson and D. J. Eldridge, "Pasture status in a semi-arid rangeland," Int. J. Remote Sens. 14(13), 2535-2546 (1993), http://dx.doi.org/10.1080/01431169308904291.

22. J. W. Rouse et al., "Monitoring vegetation systems in the Great Plains with ERTS," in The Third Earth Resources Technology Satellite-1 Symposium, Vol. 1, pp. 309-317, 10-14, NASA Scientific and Technical Information Office, Washington, DC (1974).

23. R. S. Defries and J. R. G. Townshend, "NDVI-derived land cover classifications at a global scale," Int. J. Remote Sens. 15(17), 3567-3586 (1994), http://dx.doi.org/10.1080/ 01431169408954345.

24. J. M. Paruelo et al., "ANPP estimates from NDVI for the central grassland region of the U.S.," Ecol. 78(3), 953-958 (1997), http://dx.doi.org/10.1890/0012-9658(1997)078[0953: AEFNFT]2.0.CO;2.

25. A. A. Souza, L. S. Galvão, and J. R. Santos, "Relationships between Hyperion-derived vegetation indices, biophysical parameters, and elevation data in a Brazilian savannah environment," Remote Sens. Lett. 1(1), 55-64 (2010), http://dx.doi.org/10.1080/ 01431160903329364.

26. C. L. Wiegand et al., "Vegetation indices in crop assessment," Remote Sens. Environ. 35(1), 105-119 (1991), http://dx.doi.org/10.1016/0034-4257(91)90004-P.

27. R. L. Weiser et al., "Assessing grassland biophysical characteristics from spectral measurements," Remote Sens. Environ. 20(2), 141-152 (1986), http://dx.doi.org/10.1016/0034 $-4257(86) 90019-2$.

28. G. L. Anderson, J. D. Hanson, and R. H. Haas, "Evaluating Landsat Thematic Mapper derived vegetation indices for estimating above-ground biomass on semiarid rangelands," Remote Sens. Environ. 45(2), 165-175 (1993), http://dx.doi.org/10.1016/0034-4257(93) 90040-5.

29. H. D. Williamson, "Developing a methodology for estimating grassland variables with remotely sensed data," Area 24(1), 36-44 (1992).

30. S. W. Todd, R. M. Hoffer, and D. G. Milchunas, "Biomass estimation on grazed and ungrazed rangelands using spectral indices," Int. J. Remote Sens. 19(3), 427-438 (1998), http://dx.doi.org/10.1080/014311698216071.

31. X. Guo, K. P. Price, and J. M. Stiles, "Grassland discriminant analysis using Landsat TM single and multispectral data," Photogram. Eng. Remote Sens. 69(11), 1255-1262 (2003).

32. Y. Zha et al., "A spectral reflectance-based approach to quantification of grassland cover from Landsat TM imagery," Remote Sens. Environ. 87(2), 371-375 (2003), http://dx.doi .org/10.1016/j.rse.2003.05.001.

33. M. J. Hill et al., "Estimation of pasture growth rate in the south west of Western Australia from AVHRR NDVI and climate data," Remote Sens. Environ. 93(4), 528-545 (2004), http://dx.doi.org/10.1016/j.rse.2004.08.006.

34. J. Gao, "Quantification of grassland properties: how it can benefit from geoinformatic technologies?," Int. J. Remote Sens. 27(7), 1351-1365 (2006), http://dx.doi.org/10.1080/ 01431160500474357. 
35. A. R. Huete and C. Justice, "MODIS vegetation index (MOD13) algorithm theoretical basis document," Version 3, NASA Goddard Space Flight Center, http://modis.gsfc.nasa.gov/ data/atbd/atbd_mod13.pdf (June 2010).

36. A. R. Huete et al., "Overview of the radiometric and biophysical performance of the MODIS vegetation indices," Remote Sens. Environ. 83(1-2) 195-213 (2002), http://dx.doi.org/10 .1016/S0034-4257(02)00096-2.

37. X. Xiao et al., "Modeling gross primary production of temperate broadleaf deciduous forests using satellite images and climate data," Remote Sens. Environ. 91(2), 256-270 (2004), http://dx.doi.org/10.1016/j.rse.2004.03.010.

38. Y. Kim et al., "Spectral compatibility of vegetation indices across sensors: band decomposition analysis with Hyperion data," J. Appl. Rem. Sens. 4(1), 043520 (2010), http://dx.doi .org/10.1117/1.3400635.

39. R. J. Kauth and G. S. Thomas, "The Tasseled Cap-a graphic description of the spectraltemporal development of agricultural crops as seen by Landsat," in Proc. Symposium on Machine Processing of Remotely Sensed Data, Purdue University, West Lafayette, Indiana (1976).

40. E. P. Crist and R. C. Circone, "A physically-based transformation of thematic mapper data-the TM Tasseled Cap," IEEE. Trans. Geosci. Remote Sens. GE-22(3), 256-263 (1984), http://dx.doi.org/10.1109/TGRS.1984.350619.

41. M. A. Friedl et al., "Estimating grassland biomass and leaf area index using ground and satellite data," Int. J. Remote Sens. 15(7), 1401-1420 (1994), http://dx.doi.org/10.1080/ 01431169408954174.

42. C. C. Dymond, D. J. Mladenoff, and V. C. Radeloff, "Phenological differences in Tasseled Cap indices improve deciduous forest classification," Remote Sens. Environ. 80(3), 460-472 (2002), http://dx.doi.org/10.1016/S0034-4257(01)00324-8.

43. A. A. Ager and K. E. Owens, Characterizing meadow vegetation with multitemporal Landsat thematic mapper remote sensing, Pacific Northwest Research Station, USDA Forest Service, Portland, OR (2004).

44. S. P. Healey et al., "Comparison of Tasseled Cap-based Landsat data structures for use in forest disturbance detection," Remote Sens. Environ. 97(3), 301-310 (2005), http://dx.doi .org/10.1016/j.rse.2005.05.009.

45. A. R. Huete, "A soil-adjusted vegetation index (SAVI)," Remote Sens. Environ. 25(3), 295-309 (1988), http://dx.doi.org/10.1016/0034-4257(88)90106-X.

46. N. H. Broge and E. Leblanc, "Comparing prediction power and stability of broadband and hyperspectral vegetation indices for estimation of green leaf area index and canopy chlorophyll density," Remote Sens. Environ. 76(2), 156-172 (2001), http://dx.doi.org/10.1016/ S0034-4257(00)00197-8.

47. W. J. D. van Leeuwen, "Visible, near-IR, and shortwave IR spectral characteristics of terrestrial surfaces," Chapter 3 in SAGE Handbook of Remote Sensing, T. A. Warner, M. D. Nellis, and G. M. Foody, Eds., SAGE, London, pp. 32-50 (2009).

48. J. C. Sencindiver and J. T. Ammons, "Minesoil genesis and classification," Chapter 8 in Reclamation of Drastically Disturbed Lands, R. I. Barnhisel, R. G. Darmody, and W. L. Daniels, Eds., ASA, CSSA, and SSSA, Madison, Wisconsin, pp. 595-613 (2000).

49. V. A. Akala and R. Lal, "Soil organic carbon pools and sequestration rates in reclaimed minesoils in Ohio," J. Environ. Qual. 30(6), 2098-2104 (2001), http://dx.doi.org/10 .2134/jeq2001.2098.

50. L. B. Guo and R. M. Gifford, "Soil carbon stocks and land use change: a meta analysis," Global Change Biol. 8(4), 345-360 (2002), http://dx.doi.org/10.1046/j.1354-1013.2002 .00486.x.

51. A. R. Colmer and K. L. Temple, "An iron-oxidizing bacterium from the acid drainage of some bituminous coal seams," J. Bacter. 59(3), 317-328 (1950).

52. West Virginia Surface Mining Reclamation Rule, Title 38, Series 2, http://www.wvsos.com/ csr/verify.asp? TitleSeries=38-02 (June 2009).

53. National Oceanic and Atmospheric Administration-National Climate Data Center (NOAA-NCDC), http://www.ncdc.noaa.gov/oa/ncdc.html (June 2009). 
54. E. L. Braun, Deciduous Forests of Eastern North America, Blakiston Co., Philadelphia, Pennsylvannia (1950).

55. B. J. Patton, Soil Survey Preston County West Virginia, Vol. 3, United States Department of Agriculture (USDA), Charleston, West Virgina, West Virginia Agriculture Experiment Station (1959).

56. E. L. Wright et al., Soil Survey Marion and Monongalia Counties West Virginia, United States Department of Agriculture (USDA), Charleston, West Virginia, West Virginia Agriculture Experiment Station (1982).

57. H. Jenny, The Soil Resource, Springer-Verlag, New York (1980).

58. X. Chen et al., "Monitoring boreal forest leaf area index across a Siberian burn chronosequence: a MODIS validation study," Int. J. Remote Sens. 26(24), 5433-5451 (2005), http://dx.doi.org/10.1080/01431160500285142.

59. K. M. de Beurs and G. M. Henebry, "A statistical framework for the analysis of long image time series," Int. J. Remote Sens. 26(8), 1551-1573 (2005), http://dx.doi.org/10.1080/ 01431160512331326657.

60. A. Koltunov, O. Crouvi, and E. Ben-Dor, "Geomorphologic mapping from hyperspectral data, using Gaussian mixtures and lower confidence bounds," Int. J. Remote Sens. 27(20), 4545-4566 (2006), http://dx.doi.org/10.1080/01431160600784242.

61. West Virginia Surface Mining Reclamation Rule, Title 38, Series 2, http://www.wvsos.com/ csr/verify.asp?TitleSeries=38-02 (June 2009).

62. C. D. Bonham, Measurements for Terrestrial Vegetation, John Wiley and Sons, New York (1989).

63. USGS Global Visualization Viewer, http://glovis.usgs.gov/index.shtml, (2009).

64. P. Chavez, "Image-based atmospheric corrections-revisited and improved," Photogram. Eng. Remote Sens. 62(9), 1025-1036 (1996).

65. D. Lu et al., "Assessment of atmospheric correction methods for Landsat TM data applicable to Amazon basin LBA research," Int. J. Remote Sens. 23, 2651-2671 (2002), http://dx .doi.org/10.1080/01431160110109642.

66. J. E. Vogelmann et al., "Effects of Landsat 5 Thematic Mapper and Landsat 7 Enhanced Thematic Mapper Plus radiometric and geometric calibration and corrections on landscape characterization," Remote Sens. Environ. 78(1-20), 55-70 (2001), http://dx.doi.org/10 .1016/S0034-4257(01)00249-8.

67. B. L. Markham et al., "Landsat sensor performance: history and current status," IEEE Trans. Geosci. Remote Sens. 42(12), 2691-2694 (2004), http://dx.doi.org/10.1109/TGRS.2004 .840720 .

68. National Aeronautics and Space Administration (NASA), http://landsat.gsfc.nasa.gov/ (June 2009).

69. C. Zhang, W. Li, and D. Travis, "Gaps-fill of Landsat ETM+ satellite image using a geostatistical approach,” Int. J. Remote Sens. 28(22), 5103-5122 (2007), http://dx.doi.org/10 $.1080 / 01431160701250416$.

70. S. K. Maxwell, G. L. Schmidt, and J. C. Storey, "A multi-scale segmentation approach to filling gaps in Landsat ETM+ SLC-off images," Int. J. Remote Sens. 28(23), 5339-5356 (2007), http://dx.doi.org/10.1080/01431160601034902.

Biographies and photographs of the authors not available. 